\title{
KOSI EJE KOSI ORISA: RACISMO RELIGIOSO E CRIMINALIZAÇÃO DAS RELIGIÕES DE MATRIZ AFRICANA NO PROJETO DE LEI Nº 2301999
}

\section{Luciana de Souza Ramos ${ }^{1}$}

\section{Resumo}

Como uma religião que cultua a força viva da natureza, os orixás, tudo que é feito dentro dos terreiros vem e voltam para ela. O presente trabalho visa analisar a dimensão do racismo religioso e o processo de criminalização contra as religiões de matriz africana, pela imolação de animais, a partir do Projeto de Lei (PL) 230/1999 do Estado do Rio Grande do Sul. A metodologia é bibliográfica, por meio da análise constitucional do PL, bem como da decisão Supremo Tribunal Federal (STF).

Palavras-chave: Racismo religioso; Imolação animais; Liberdade religiosa; Criminalização; Candomblé.

\section{KOSI EJE KOSI ORISA: RELIGIOUS RACISM AND CRIMINALIZATION OF AFRICAN-BASED RELIGIONS IN BILL NO. 2301999}

\begin{abstract}
As a religion that worships the living force of nature, orishas, everything that is done within the terreiros comes and goes to it. The present work aims to analyze the dimension of religious racism and the process of criminalization against the religions of African matrix, for the immolation of animals, from the Bill 230/1999 from Rio Grande do Sul. The methodology is bibliographic, through the constitutional analysis of the Bill, as well as the Supreme Court (STF) decision.
\end{abstract}

Keywords: Religious racism; Animal immolation; Religious freedom; Criminalization; Candomblé.

\section{INTRODUÇÃO}

Bi ewe yeje para lala ie, Ògún pere pa"2. Iniciamos este artigo, apresentando nossas opções acadêmicas e políticas dos caminhos teóricos e sensíveis percorridos. A iniciar pela opção de escrita compartilhada e localizada das autoras, cujo pertencimento é ao mesmo

\footnotetext{
${ }^{1}$ Doutora em Direito Constitucional e Teoria do Estado pela Universidade de Brasília (UNB). Pesquisadora dos grupos de pesquisa O Direito Achado na Rua e do Grupo Candango de Criminologia da UNB. Advogada da Rede Nacional de Advogados e Advogadas Populares (RENAP), bem como dos Coletivos Marietta Baderna e Luísa Mahin. E_mail: luciana.adv.mab@gmail.com

${ }^{2}$ Frase de Mãe Stella de Oxóssi, cuja tradução da cantiga é: Demos-lhes um novo nascimento, você resistiu à prova, ultrapassou seguramente privações e sofrimentos, você não está morto, está vivo. Somente Ogum mata. Disponível em: https://candombledabahia.wordpress.com/2013/07/29/ritual-esacrificio-no-candomble/
} 
tempo acadêmico e pessoal, pois somos parte do que hora refletimos, sem qualquer constrangimento nesta afirmação, uma vez que compreendemos o conhecimento como localizado. Todo conhecimento é um personagem, situado, com cor, com gênero, com posição social e repleto de intencionalidades. Assim é este artigo. Assim é a compreensão de conhecimento pressuposto desta produção.

A segunda opção, acadêmica e política assumida por nós, é a Amefricanização ${ }^{3}$ do conhecimento com o objetivo de repensarmos e recolocarmos a construção dos saberes a partir, não somente dos (as) subalternos (as) ${ }^{4}$, mas, principalmente, do conhecimento produzido a partir de outras lógicas e dimensões sociais, vilipendiadas e sufocadas pelo processo colonial. Assim, fundamental o rompimento com a produção acadêmica hermética, impessoal, universal e objetificante.

Desta forma, iniciamos rompendo com o léxico acadêmico da impessoalidade, da idéia de "pesquisador" (sujeito-objeto ${ }^{5}$ ) distante do "objeto" (sujeito), para nos situar enquanto pesquisadoras (sujeito-parte), mulheres, candomblecistas, que vivemos a religiosidade de matriz africana não apenas pela dimensão espiritual, mas pela dimensão de vida, o que significa dizer que não falamos sozinhas, pois nossa fala é coletiva, é situada e está plantada no Terreiro junto com o Iroko $^{6}$.

Compartilhada, portanto, nossas dimensões acadêmicas, importante situar que a escolha deste tema se dá por dois grandes motivos. Um primeiro, religioso de dimensão cosmológica do significado da imolação para nós; e o segundo, jurídico-político, de fissura do modelo de estado democrático, constitucional e laico.

Para trabalhar com as tradições religiosas de matriz africana é preciso despir-se de um imaginário branco, ocidental e cristão e abrir-se para outra dimensão, onde a subjetivação, a crença e a política, enquanto colocar-se como sujeito político no mundo, é umbilical. E partindo desse pressuposto, despir-se também da idéia essencialista - também um discurso branco de legitimação da cultura negra - de que para ser religião afro-brasileira precisa refletir ou transcender uma África no Brasil, ou seja, é importante pensar nessas religiões

\footnotetext{
${ }^{3}$ Categoria desenvolvida por Lélia Gonzalez para aduzir novos elementos a uma categorização dos direitos humanos que possa ser apreensível em pretuguês.

${ }^{4}$ SPIVAK

${ }^{5}$ Achile Mbembe. Crítica da razão negra.

${ }^{6}$ Árvore sagrada que simboliza a ligação do presente com o passado, dos mais novos com os mais velhos, do conhecimento presente com a ancestralidade.
} 
como não estáticas, ao contrário, elas são dinâmicas e claramente mutáveis com o passar do tempo, imensurável por nossa tradição cristã e materialista.

O Estado Moderno é fundado a partir da ideia de separação entre Estado e Religião ${ }^{7}$, numa perspectiva em que os fundamentos estatais devem guardar compromisso com a razão e não mais com a divindade, a sua fundamentação não pode mais, portanto, estar baseada nos ditames divinos. Contudo, esse distanciamento não reflete numa cisão real entre Estado e Religião, ao contrário, a conciliação da burguesia com a Igreja será garantida a partir da ideia universalista, eurocêntrica e cristã da humanidade, principalmente, na relação com "novos povos descobertos".

No Brasil, ao mesmo tempo em que há a garantia, a partir da Constituição Republicana de 1891, da separação entre Estado e Igreja, consequentemente o direito à liberdade religiosa, há por outro lado, um discurso de anormalidade e inferioridade racial da população negra que passa a justificar a vigilância e repressão das religiões Afro-brasileiras, negando, consequentemente a liberdade religiosa.

As discussões atuais sobre respeito ao direito à liberdade de culto e religioso vêm permeando o cenário jurídico e social, estimulando reflexões sobre a importância de se reconhecer e respeitar a diversidade étnico-racial e, consequentemente, as manifestações culturais, religiosas e cosmológicas, para que o direito insculpido nos arts. $5^{\circ}$, VI e VII e 19, I da Constituição Federal de 1988 sejam efetivados.

Há muito que as religiões de matriz africana são visualizadas como espaços de sociabilidade negativos, seja pela equivocada compreensão, de que são espaços que "praticam o mal", seja pela formação cristã colonizadora que centraliza no cristianismo a afirmação da cosmologia da fé, fazendo com que todas as demais expressões religiosas sejam vistas como "não religiosas", justificada pelo modelo colonizador, eurocêntrico e cristão.

Assim, este artigo tem como metodologia a análise teórica e documental do projeto de lei em tramitação no Congresso Nacional 230/1999, bem como o Recurso especial que tramita

\footnotetext{
${ }^{7} \mathrm{O}$ debate, portanto, sobre laicidade do estado tem sido fundamental para a reconfiguração e reafirmação dos direitos humanos. Pensar num Estado laico, não é pensar num "Estado ateu", ao contrário, pensar num Estado laico é pensar e afirmar um Estado pluriétnico, intercultural, não confessional e plurireligioso. Afirmamos direitos reconhecendo a diversidade.
} 
no STF.

\section{A EFABUlaÇão do NEGRO E SUAS PRÁticas REligiosas: beSTIALIDAde E SATANIZAÇÃO DAS RELIGIÕES DE MATRIZ AFRICANA.}

O ser negro, construção imaginária erigida no processo de efabulação, sustentada pelo conceito de raça, forjado pela empresa colonial, era tido como "o exemplo total deste seroutro, fortemente trabalhado pelo vazio, e cujo negativo acabava por penetrar todos os momentos da existência - a morte do dia, a destruição e o perigo, a inominável noite do mundo (MBEMBE, 2014, p. 28).

O processo de violação da cultura negra durante a colonização latinoamericana forjou como negativa a identidade (de matriz) africana e tudo que decorria dessa expressão. "O mito da Modernidade", centrado na Europa como único local de produção e difusão de conhecimento, exclui tudo e todos que estão na periferia. $\mathrm{O}$ resto é criado pelo "dissemelhante, da diferença e do poder puro do negativo" (MBEMBE, 2014, p. 29). A modernidade desenvolve um "mito" irracional, de justificação da violência, que Dussel convida a superar $(1993$, p. $07 ; 60)$ :

Todo o mundo imaginário do indígena (do negro) era "demoníaco" e como tal devia ser destruído. Esse mundo do Outro era interpretado como o negativo, pagão, satânico e intrinsecamente perverso. O método da tabula rasa era o resultado coerente, a conclusão de um argumento: como a religião indígena (e negra) é demoníaca, e a europeia divina, a primeira deve ser totalmente negada.

Assim, a escravidão não foi só um horror pela forma como (não) enxergou os seres humanos, mas principalmente porque incentivou e reforçou a destruição identitária de homens e mulheres negras. Assim como toda expressão cultural que derivasse dos negros, as religiões de matriz africana ${ }^{8}$ ou afro-brasileiras ${ }^{9}$, como preferem alguns, foram perseguidas e

\footnotetext{
${ }^{8}$ Sem desconhecer a polêmica em torno dos conceitos, melhor conceituá-los para melhor entendimento do tema. As religiões de matriz africana se preservam mais efetivamente a tradição africana. De forma genérica, pode-se considerar como "conjunto de expressões religiosas que têm em comum uma origem: a África, e que é, então, étnico-racial. A par dos códigos e símbolos que as unificam há um conjunto de diferenças, de crenças que estabelecem particularidades, desde o Candomblé e Umbanda, até a Jurema e os Encantados" - religiões afro-
} 
criminalizadas, passando por um profundo processo de en-cobrimento e silenciamento (RAMOS, 2019, p. 42), imposto pela biopolítica do embranquecimento, ou pela necropolítica como sugere MBEMBE (2006).

A maquiagem utilizada para descaracterização da identidade negra forja identidades negativas, como afirma Stuart Hall, na qual a imagem está sempre associada, refletida, construída socialmente ao degenerativo, ao inferior, ao não humano. Por isso, Hall salienta o conceito e a afirmação de "raça", pois a concebe como uma categoria discursiva e não uma categoria biológica. Ela é a categoria organizadora daquelas formas de falar, daqueles sistemas de representação e práticas sociais (discursos).

A negação da identidade da população negra vai refletir nas várias tentativas de insurgência, seja, desde a Revolta dos Malés, aqui no Brasil, passando pelas resistências quilombolas até sua intensificação na luta dos movimentos negros. Verdade é que forjar o povo negro na concretização da cidadania ativa significou resgatar também a identidade maquiada pela biopolítica do embraquecimento, salientado por Stuart Hall, no processo de afirmação da "raça", a partir da reconstrução da identidade positiva dos (as) negros(as).

A história da ascensão social do negro brasileiro é, assim, a história de sua assimilação aos padrões brancos de relações sociais. E a história da submissão ideológica de um estoque racial em presença de outro que se lhe faz hegemônico. É a história de uma identidade renunciada, em atenção às circunstâncias que estipulam o preço do reconhecimento ao negro com base na intensidade de sua geração.O negro que se empenha na conquista da ascensão social paga o preço do massacre mais ou menos dramático de sua identidade. Afastado de seus valores originais, representados fundamentalmente por sua herança religiosa, o negro tomou o branco como modelo de identificação, como única possibilidade de "tornar-se gente". (SOUSA apud Pascual, 2005).

O esforço de realizar esta discussão assenta-se na busca de contribuir para a inserção e

brasileiras marcadas pela presença de entidades, com forte presença no norte e nordeste do Brasil. (TORRES, 2009, p. 29).

${ }^{9}$ As afro brasileiras "sintetizam outros elementos culturais à matriz africana, além do que se concretizam em uma territorialidade específica, em suas dimensões ambientais, históricas e culturais, o Brasil, que dá novas dimensões à matriz africana". (TORRES, 2009, p. 11-12) 
reconhecimento das práticas Afro religiosas latinoamericanas, na luta por direitos, reconstruídas na diáspora, na dinâmica sócio-jurídica, reflexo da transnacionalização da condição negra, forjada no Atlântico negro, no processo de criolização que a triangulazão comercial (Europa, Américas e Africa) estabeleceu, e que foi para além de um comércio de "negros-africanos", mas representou o tráfego de religiões, tecnologias e culturas, que com as estruturas imperiais do mundo atlântico arruinadas e substituídas pelos Estados nações, forjarão alterações significativas nas colônias (MBEMBE, 2014, p. 33):

Não se trata somente de cargueiros humanos que, partindo de entrepostos e portos de escravos de África Ocidental e da baía do Biafra, depositam homens na Jamaica e nos Estados Unidos. Lado a lado com o macabro comércio de escravos, cujo objetivo é o lucro existem também movimentos de africanos livres, novos colonos, (...). As velhas questões de heretogeneidade, diferença e liberdade são ressuscitadas, enquanto as novas elites se apropriam da ideologia da mestiçagem para negar e desvalorizar a questão racial.” (Idem, p.35).

A razão irmã siamesa da linguagem vai forjar uma racionalidade negra, racial e teórica livre de qualquer ligação com a realidade:

La propia cultura letrada podría constituir la mayor carcél epistemológica como obstáculo para uma Elemental comunicación intercultural, no solo para uma aproximación AL pasado Del proceso civilizatório, sino también al presente Del proyecto constitucional multicultural. La necesidad de afinar nuestras herramientas epistêmicas para revalorar otros instrumentos de percepción y de comunicación no tan valorados em nuestra cultura escrituraria como lo son em las culturas (afro) y indígenas. (GAITÁN, 2014, p.08)

A dimensão religiosa não foi apenas uma sensibilidade cosmológica de supressão do outro, foi instrumento real de (en)cobrimento do outro no projeto moderno, estando imbricada na própria razão do comércio marítimo, no processo de colonização e de criação dos Estados Nacionais. A Colômbia é um dos principais exemplos na América Latina: 
A partir de 1886, com a Constituição deste ano, se apresenta um grande projeto de construção de nação, talvez o maior e mais forte que já houve no país, contudo sob a égide conservadora e católica. Uma fé, uma língua, um símbolo religioso, um sistema educativo, um sistema político que são a expressão mais pura da nação colombiana. Ser colombiano é ser católico e vice-versa, pois desde o princípio se era católico (tradução livre). (ARBOLEDA, 2000, p. 06).

Procura-se, portanto, com este estudo o encontro da religião como um elemento permanente nas sociedades humanas e dentro de um "mundo policêntrico", compreender as dimensões deste processo político e "simbólico" nas sensibilidades e nas sociabilidades, pensando, consequentemente, no processo de afirmação, não só enquanto negros e negras, mas na afirmação enquanto sujeitos de direitos.

Desta forma, buscar-se-á analisar como as religiões Afro-brasileiras e Afrocolombianas se inserem no campo do direito, como intervenções de uma práxis constitucional legítima, para efetivação do direito à liberdade de culto e religioso. Para tanto, necessário, compreender, a partir da história social de intolerância e discriminação racial presentes no seio da sociedade e das ações do Estado, a construção de discursos, ora científicos, ora jurídicos legitimadores da não realização do direito à liberdade religiosa, previstos nos arts. 5, VI e VII e 19, I da Constituição Federal de 1988 e no art. 19 da Constituição Colombiana.

O direito pouco tem se debruçado sobre essa questão, sendo fundamental a abertura para o estudo, pois a intolerância e a violência vivenciada pelos adeptos das religiões afrodiaspóricas apresentam-se cotidianamente e transversalizam a atuação do poder público como um todo. Necessário, aos pesquisadores em direito refletirem criticamente a respeito.

A presente pesquisa, portanto, buscará (re)construir o direito à liberdade religiosa e de culto pelo diálogo intercultural entre religiões Afrodiaspóricas, entendendo todo o processo histórico brasileiro e colombiano e a relação com a população negra, conseqüentemente com as religiões Afro, que forjaram discursos deslegitimadores de direitos para as comunidades religiosas negras. A tentativa de construção de um cenário de e para esse diálogo, a partir da luta por direito, será a utopia desta pesquisa. 


\section{A JUSTIÇA DE XANGÔ NO BANCO DOS RÉUS: LAICIDADE E CONSTITUIÇÃO FEDERAL DE 1988}

No dia 3 de novembro de 2016, o Ministro Marco Aurélio, do Supremo Tribunal Federal, liberou para julgamento o Recurso Extraordinário sobre o sacrifício de animais nas religiões afro-brasileiras - pauta que já se estende há mais de dez anos, cujo referido ministro é relator do recurso desde setembro de 2006.

Em 2003, a Assembleia Legislativa do Rio Grande do Sul aprovou o Código Estadual de Proteção de Animais (Lei 11.915/03), proposta pelo Deputado e então pastor evangélico Manoel Maria em 1999 (PL 230 1999), cuja redação do segundo artigo versa:

I - ofender ou agredir fisicamente os animais, sujeitando-os a qualquer tipo de experiência capaz de causar sofrimento ou dano, bem como as que criem condições inaceitáveis de existência;

II - manter animais em local completamente desprovido de asseio ou que lhes impeçam a movimentação, o descanso ou os privem de ar e luminosidade;

III - obrigar animais a trabalhos exorbitantes ou que ultrapassem sua força; IV - não dar morte rápida e indolor a todo animal cujo extermínio seja necessário para consumo;

$\mathrm{V}$ - exercer a venda ambulante de animais para menores desacompanhados por responsável legal;

VI - enclausurar animais com outros que os molestem ou aterrorizem;

VII - sacrificar animais com venenos ou outros métodos não preconizados pela Organização Mundial da Saúde - OMS -, nos programas de profilaxia da raiva. (BRASIL, 1999)

Apesar de nenhum parágrafo do artigo proibir expressamente o sacrifício de animais em rituais religiosos, líderes das religiões de matriz africana ${ }^{10}$, que já estavam se organizando

6 Sem desconhecer a polêmica em torno dos conceitos, melhor conceituá-los para melhor entendimento do tema. As religiões de matriz africana se preservam mais efetivamente a tradição africana. De forma genérica, pode-se considerar como "conjunto de expressões religiosas que têm em comum uma origem: a África, e que é, então, étnico-racial. A par dos códigos e símbolos que as unificam há um conjunto de diferenças, de crenças que estabelecem particularidades, desde o Candomblé e Umbanda, até a Jurema e os Encantados" - religiões afro-brasileiras marcadas pela presença de entidades, com forte presença no norte e nordeste do Brasil. (TORRES, 2009, p. 29).

${ }^{7}$ As religiões afro-brasileiras "sintetizam outros elementos culturais à matriz africana, além do que se concretizam em uma territorialidade específica, em suas dimensões ambientais, históricas e culturais, o Brasil, que dá novas dimensões à matriz africana”. (TORRES, 2009, p. 11-12) 
em uma Comissão/Congregação em Defesa das Religiões Afro-brasileiras (CDRA), preocuparam-se com o projeto de lei e se mobilizaram prevendo uma possível interpretação fundamentada no preconceito para a proibição do sacrifício ritual de animais em seus cultos, que de fato ocorreu.

A CDRA se articulou e teve o apoio do Deputado Estadual Edson Portilho que apresentou na Assembleia Legislativa o projeto de lei 282/03, para estabelecer exceção no artigo segundo do Código de Proteção de Animais para os rituais de religião de matriz africana, com base no parágrafo seis do artigo quinto da Constituição federal, "é inviolável a liberdade de consciência e de crença, sendo assegurado o livre exercício dos cultos religiosos e garantida, na forma da lei, a proteção aos locais de culto e a suas liturgias" (BRASIL, 2003).

Após uma grande discussão, tanto na Assembleia, quanto na mídia local, o projeto do deputado Edson Portilho foi aprovado com 32 (trinta e dois) votos a favor e 2 (dois) contrários, e o Código de Proteção dos Animais, no seu artigo segundo recebeu nova redação ao final: "Parágrafo único - Não se enquadra nessa vedação o livre exercício dos cultos e liturgias das religiões de matriz africana. (Incluído pela Lei $\left.n^{\circ} 12.131 / 04\right)$ '”.

No ano seguinte, abril de 2005, o Procurador-Geral de Justiça do Estado apresentou uma Ação Direta de Inconstitucionalidade (ADI 70010129690) no Tribunal de Justiça, solicitando a retirada da lei do Deputado Portilho, por considerá-la inconstitucional no plano formal e material. Sendo formal, por não ser competência de o Estado legislar sobre questão penal (o crime de maus-tratos), sendo competência da União (Federal). Material, por infringir o princípio da isonomia, da igualdade de direitos de todas as religiões, de forma que a lei só permite a exceção às religiões afro-brasileiras, e desconsidera outras que também fazem sacrifícios, como o Islamismo e o Judaísmo.

De acordo com Mateus Lúcio Mamede (2012), a Constituição estabelece sua força vinculante ao Poder Público, devendo ser reconhecida a sua supremacia, e um controle de constitucionalidade deve ser exercido para que todas as normas do Estado se adequem a ela para a garantia da ordem e da coerência do sistema jurídico e do Estado Democrático de Direito. Dentre os tipos de inconstitucionalidade, encontram-se a formal e a material.

Nesse sentido, Mamede (2012) explica a inconstitucionalidade formal como "os vícios relativos à formalidade, (que) afetam o ato normativo sem atingir seu conteúdo, referindo-se aos procedimentos e pressupostos relativos às feições que formam a lei”. Ou seja, as 
inobservâncias dos princípios técnicos e procedimentais em relação à atribuição de competência dos órgãos públicos ou de inobservância do processo legislativo próprio acarretariam a inconstitucionalidade formal, conforme ocorrera no caso em tela.

A distribuição da competência legislativa privativa à União em matéria de Direito Penal encontra-se na Constituição Federal de 1988, que assim dispõe:

Art. 22. Compete privativamente à União legislar sobre: I - direito civil, comercial, penal, processual, eleitoral, agrário, marítimo, aeronáutico, espacial e do trabalho [...]. (BRASIL, 1988)

Quanto à inconstitucionalidade informal, ligada aos vícios materiais, Mamede (2012) ensina que "estão ligados ao próprio mérito do ato, referindo-se a conflitos de regras e princípios estabelecidos na Constituição". Para melhor ilustrar, o autor cita Branco; Coelho; Mendes:

É possível que o vício de inconstitucionalidade substancial decorrente do excesso de poder legislativo constitua um dos mais tormentosos temas do controle de constitucionalidade hodierno. Cuida-se de aferir a compatibilidade da lei com os fins constitucionalmente previstos ou de constatar a observância do princípio da proporcionalidade, isto é, de se proceder à censura sobre a adequação e a necessidade do ato legislativo. (BRANCO; COELHO; MENDES, 2010, p. 1172, citado por MAMEDE, 2012).

O princípio da isonomia, também conhecido como princípio da igualde, citado pelo Procurador-Geral de Justiça do Estado em 2005 ao apresentar a ADI de número 70010129690 é considerado um dos pilares do Estado Democrático de Direito, sendo, inclusive, citado na Declaração Universal dos Direitos Humanos. Trata-se de um princípio amplo e expressivo que deve ser cautelosamente analisado conforme cada caso concreto.

Segundo Maria Christina Barreiros D’Oliveira (2011, p. 9), “a interpretação desse princípio deve levar em consideração a existência de desigualdades de um lado, e de outro, as injustiças causadas por tal situação, para, assim, promover-se a igualdade plena”. É nesse sentido que inconstitucionalidade da lei do Deputado Portilho fora analisada, uma vez que desprivilegiava as religiões afro-brasileiras em relação às outras. 
Apesar da inconstitucionalidade, o Procurador Geral ressaltou que a proibição do artigo segundo do Código de Proteção dos Animais aprovado antes da alteração proposta pelo deputado Edson Portilho não pode interferir ou se referir aos sacrifícios de animais dos cultos das religiões afro-brasileiras, visto que "porquanto jamais a liberdade de religião, constitucionalmente garantida, poderia ser afetada decisivamente em seu núcleo essencial por norma protetiva de animais".

A ADI foi julgada no mesmo mês e ano pelos desembargadores que mantiveram a exceção aos cultos das religiões afro-brasileira. Dessa forma, foi garantida a prática do sacrifício ritual de animais pelas religiões afro-brasileiras no Estado do Rio Grande do Sul, desde que não haja excesso ou requintes de crueldade, como também o sacrifício de animais silvestres e espécies ameaçadas de extinção. Entretanto, no ano seguinte, setembro de 2006, a decisão foi objeto de Recurso Extraordinário no Supremo Tribunal Federal pelo Ministério Público Estadual, sendo atualmente colocado em pauta para julgamento pelo Plenário do Superior Tribunal Federal.

O recurso do Ministério Público do Rio Grande do Sul não visa proibir o sacrifício de animais nos cultos ou liturgia das religiões afro-brasileira, "impedir o sacrifício ritual de animais implica, para esses cultos, a perda da própria identidade da sua expressão cultural" (ADI 70010129690), mas propõe a isonomia na prática do sacrifício, para não dar privilégio apenas a religião de matriz africana. Como também não considera o sacrifício como uma forma de tratamento cruel aos animais, para que ele seja uma exceção ao artigo que se refere a proibição de maus tratos e sofrimento aos animais.

Há de se ressaltar que o destaque ou exceção dado as religiões afro-brasileiras decorreu do conflito de intolerância e preconceito religioso, que se arrasta no Brasil há séculos.

Após aprovação da Lei 11.915/03 (Código Estadual de Proteção de Animais) em 2003, ocorreram casos de interdição e solicitação de interdição de terreiros devido à prática do sacrifício, o que impulsionou mais ainda a organização e luta da Congregação em Defesa das Religiões Afro-brasileiras pela mudança da lei, evitando esse tipo de interpretação.

Além do caso específico no Rio Grande do Sul, em 2015 ele voltou a ser discutido através de Projeto de Lei 21/2015, da deputada Regina Becker Fortunati, que pretendia alterar o Código de Defesa dos Animais para o texto original com o intuito de proibir o sacrifício de animais nos cultos das religiões de matriz africana, não tendo êxito. Outros projetos de leis 
com a mesma finalidade explicitamente foram discutidos nos municípios de Piracicaba/SP (2010), Santo André/SP (2011), Salvador/BA, São José do Rio Preto/SP (2015), com o mesmo resultado, exceto o caso mais recente no município de Cotia/SP, com a aprovação da lei 1960/2016, que proíbe a utilização e sacrifício de animais em rituais e cultos.

De acordo com a Associação Cívica República e Laicidade, a laicidade é uma "forma institucional que toma nas sociedades democráticas a relação política entre o cidadão e o Estado, e entre os próprios cidadãos”. Dessa forma, para garantir a liberdade individual e coletiva, afasta o domínio público do privado, onde nenhum grupo pode obrigar suas convicções próprias a outros, e cada um tem o direito de optar pela convicção que lhe parecer pertinente.

Assim, segundo a organização:

\begin{abstract}
A Laicidade garante a todo o indivíduo o direito de adoptar uma convicção, de mudar de convicção, e de não adoptar nenhuma. A Laicidade do Estado não é portanto uma convicção entre outras, mas a condição primeira da coexistência entre todas as convicções no espaço público. Todavia, nenhuma liberdade sendo absoluta e todo o direito supondo deveres, os cidadãos permanecem submetidos às leis que se deram a si próprios. (ASSOCIAÇÃO REPÚBLICA E LAICIDADE)
\end{abstract}

A partir da instituição do Decreto 119-A de 07/01/1980, assinado pelo Marechal Manoel Deodoro da Fonseca, o Brasil teria se tornado um Estado laico, de forma que o país deixaria de reconhecer o catolicismo romano como religião oficial e passaria a efetivar e estender a liberdade religiosa.

Segundo Andrea Russar (2012), até tal advento, apesar de haver a liberdade de crença no Brasil, a liberdade de culto era restringida aos lares dos praticantes, com exceção dos cultos da religião compreendida como oficial. Dessa forma, institui o Decreto 119-A de 1890 que "prohibe a intervenção da autoridade federal e dos Estados federados em matéria religiosa, consagra a plena liberdade de cultos, extingue o padroado e estabelece outras providencias" (BRASIL, 1890, ipsis verbis). O presente decreto fora revogado pelo Decreto $\mathrm{n}^{\mathrm{o}} 11$ de 1991 e teve sua vigência reestabelecida pelo Decreto $\mathrm{n}^{\mathrm{o}} 4.496$ de 2002.

Considerando que a laicidade é um processo decorrente do amadurecimento social, Joana Zylbersztajn (2012, p. 85) estabelece dois eixos que devem ser levados em 
consideração para a real separação entre igreja e Estado, sendo o primeiro o aspecto legal, já realizado, e o segundo a "privatização da moralidade e da religião".

No entendimento da autora, os grupos religiosos não poderiam influenciar da forma que influenciam o processo legislativo e de políticas públicas, ressaltando como preocupante a presença de tantos delegados religiosos nas casas legislativas, sendo a estrita separação entre esferas públicas e privadas insuficiente para garantir o pluralismo das religiões e dos povos (ZYLBERSZTAJN, 2012, p. 85-88).

No âmbito das Leis maiores que perpassaram o Estado brasileiro, a Constituição Imperial Brasileira de 1824, primeira constituição do Brasil, estabelecia a religião católica romana como religião oficial do país, permitindo aos seguidores das demais religiões apenas o culto em suas casas. A Constituição da República dos Estados Unidos do Brasil de 1891 apenas consolidou o Decreto 119-A de 1890, que tornara o país um estado laico. Em contrapartida, a Constituição da República dos Estados Unidos do Brasil de 1934 teria mencionado "Deus" em seu preâmbulo e reafirmado a liberdade de culto, atendendo aos limites da "ordem pública" e dos "bons costumes". Por sua vez, a Constituição da República dos Estados Unidos do Brasil de 1937 viria a reconhecer a liberdade de tudo, entretanto, não mencionando a figura de "Deus" em seu preâmbulo (RUSSAR, 2012).

Segundo Russar (2012), a figura de Deus volta a integrar o preâmbulo da Carta Magna a partir da Constituição dos Estados Unidos do Brasil de 1946, reafirmando o livre exercício dos cultos no limite da ordem pública e "bons costumes". Entretanto, a nova carta política traria inovações nos aspectos da imunidade tributária aos templos de qualquer religião, a "escusa de consciência" ${ }^{11}$, assistência religiosa a militares e internados em habilitação coletiva, a permissão de cemitérios confessionais e liberdade de ritos religiosos em qualquer cemitério, descanso remunerado em feriados religiosos e ensino religioso opcional.

A Constituição da República Federativa do Brasil de 1967/1969, outorgada sob a pressão do regime militar, manteve a "proteção de Deus" em seu preâmbulo, bem como a liberdade de culto, inovando na inserção da "colaboração entre o Estado e as organizações religiosas, no interesse público" (RUSSAR, 2012). Ainda segundo Russar (2012), “escusa de consciência" fora suprimida em virtude da perda de direitos políticos consequentes do Golpe

\footnotetext{
11 "A lei poderia estabelecer obrigações alternativas àqueles que se recusassem a cumprir obrigações impostas por lei a todos os brasileiros" (RUSSAR, 2012).
} 
Militar de 1964. Contudo, foi inserida no âmbito dos direitos e garantias individuais a afirmativa de que todos seriam iguais perante a lei, "sem distinção de credo religioso" (BRASIL, 1967). Foram mantidos nesse texto constitucional a liberdade de consciência, exercício de cultos, assistência religiosa, repouso remunerado, efeitos civis do casamento religioso, ensino religioso opcional e imunidade tributária (RUSSAR, 2012).

Por fim, segundo Russar (2012), a Constituição Federal de 1988, vigente ate os dias de hoje, teria mantido a figura de "Deus" em seu preâmbulo, prevendo, também, a liberdade relacionada ao culto, crença e religião, assistência religiosa (sem a imposição da prestação por brasileiros), e retoma a liberdade religiosa em seu artigo $5^{\circ}$, incivo IV, dispondo que "é inviolável a liberdade de consciência e de crença, sendo assegurado o livre exercício dos cultos religiosos e garantida, na forma da lei, a proteção aos locais de culto e a suas liturgias" (BRASIL, 1988). A figura da "escusa de consciência” ficaria consagrada através do art. $5^{\circ}$, inciso VIII, e não se dispõe mais a respeito da remuneração do trabalhador referente aos feriados religiosos.

Analisando a Constituição Federal de 1988, Zylbersztajn (2012, p. 27-28) ressalta "a influência religiosa no processo de construção da constituição brasileira no momento da redemocratização do país". Quanto a esse processo, para a autora, as questões religiosas foram apontadas como "de menor importância" frente às outras questões entendidas como mais essenciais ao processo constituinte do Estado. Nesse aspecto, cita, a título de exemplo, a presença da bíblia crista sobre a mesa das casas legislativas, sendo considerada irrelevante quando, na verdade, é carregada de simbolismos e influências de uma determinada religião num espaço público que exerce influência sobre uma nação plural.

Segundo a autora:

Diversos exemplos semelhantes podem ser destacados a título ilustrativo, demonstrando como a presença religiosa formal influenciou o processo constituinte. Houve, em determinado momento dos trabalhos, a proposta de incluir dispositivo que estabelecia que ninguém seria prejudicado ou privilegiado em função de sua orientação sexual. O texto foi atacado intensamente pela bancada religiosa, com argumentos religiosos, até que fosse retirado da pauta. (ZYLBERSZTAJN, 2012, p. 28)

De acordo com Russar (2012), ainda encontram-se, no Brasil, diversas referências a manifestações religiosas, como a expressão "Deus seja louvado" nas cédulas da moeda real do 
país, a atuação da "bancada religiosa" na política, a recomendação do judiciário para que tenham sensibilidade quanto aos feriados judaicos para os advogados judeus e a mudança de datas ou possibilidade de condições especiais para religiosos em concursos públicos e vestibulares, como, por exemplo, aos praticantes "adventistas do sétimo dia".

Nesse sentido, segundo a autora:

O Brasil é um estado teoricamente laico, onde, todavia, ocorrem situações que põem em xeque tal laicidade, como é o caso do uso de símbolos religiosos em locais públicos e dos feriados religiosos. Como decorrência da laicidade estatal (ainda que questionável), a Constituição Federal de 1988 confere aos indivíduos o direito não absoluto à liberdade religiosa. $\mathrm{O}$ direito à liberdade religiosa, por sua vez, é tema que tem muitos desdobramentos [...]. (RUSSAR, 2012)

Segundo Douglas Pinheiro (2008, p. 44), o questionamento quanto ao uso de símbolos religiosos é tema recorrente dentre as cortes de todo o mundo. No Plenário da Constituinte no Brasil, a exibição da bíblia cristã fora, inclusive, garantida por meio de uma norma regimental, pela qual o autor compreende ter sido uma forma de afirmação de identidade, onde se entendeu que o objeto simbólico pertencia a uma identidade cultural do povo, ou seja, um símbolo ligado ao poder hegemônico (PINHEIRO, 2008, p. 117-119).

Nesse sentido, segundo o autor:

[...] a tentativa de se religar uma identidade coletiva a um passado recriado acaba transformando a memória em bem simbólico do poder hegemônico, o que pode mostrar uma face extremamente explosiva quando o outro, pelos discursos de inferiorização, converte-se de sujeito a objeto e, depois, pelos discursos de ódio, de objeto a objeto. Aliás, dentro do processo de construção de identidades coletivas, os discursos de ódio têm sido utilizados como narrativas eficazes para interpretar traumas ou glórias antigos, estrategicamente recortados, e religar um passado recriado a um futuro projetado. (PINHEIRO, 2008, p 119-120)

Para Zylbersztajn (2012, p. 106), apesar da separação entre Estado e igreja, alguns Estados como o Brasil ainda insinuam preferência por uma determinada religião, no caso, a cristã, não podendo ser o tema das simbologias presentes no espaços públicos como 
Congresso, Senado e Supremo Tribunal Federal considerado "fútil" dentro de um país que se intitula laico.

Assim, a autora considera prejudicial para a evolução social de um estado laico esse favoritismo velado, reafirmando que este é um debate significante, pois mesmo décadas após a separação da igreja e do Estado, símbolos e referências religiosas ainda marcam presença nos espaços públicos, como a referência a "Deus" no preâmbulo da Carta Magna, nas cédulas de moeda real brasileira e em outros documentos públicos (ZYLBERSZTAJN, 2012, p. 113118).

\section{A HORIZONTALIDADE DOS PRINCÍPIOS CONSTITUCIONAIS}

Para Roseli Fischmann (2012, p. 16-17), o caráter laico do Estado permite que a diversidade e a pluralidade humana convivam entre si, sendo o direito a liberdade de crença um pressuposto básico para a efetividade desse Estado. Para a autora, a laicidade vai garantir um direito individual e coletivo do ser humano, pois " [...] é a laicidade do Estado que garante, a cada um, a possibilidade de escolher em que e como crer, ou simplesmente não crer, enquanto é plenamente cidadão, em busca e no esforço de construção da igualdade" (FISCHMANN, 2012, p. 16-17).

A esse passo, Fischmann (2012, p. 17) trata as formas de exclusão que podem ocorrer na sociedade quando alguma religião heterônoma cria um padrão que vem a caracterizar identidades como aceitáveis ou não.

Nesse sentido, segundo a autora:

Se dada religião é tomada como "melhor" ou "preferencial", comparativamente às outras religiões que estejam presentes em dada sociedade, e sejam quais forem os argumentos usados, automaticamente o grupo de adeptos dessa religião passará a gozar de privilégios e distinção que excluirão os demais. Se é o argumento da maioria estatística que se tenta usar como base da reivindicação do privilégio, mais em risco ainda se coloca a democracia [...]. (FISCHMANN, 2012, p. 17)

Assim, se a própria lei diz que as pessoas podem crer ou não crer, e se crer, crer como quiser, não pode o mesmo Estado oferecer privilégios a um determinado grupo, motivando a exclusão dos demais. "Como construir a consciência do direito a ter direitos, se o mais básico 
direito à liberdade de consciência e de crença está fragilmente exposto, à mercê de violação?" (FISCHMANN, 2012, p. 18).

Nesse sentido, Fischmann (2012, p. 18) retoma Herbert Kelman para tratar das “determinações jurídicas" que direta ou indiretamente, permitem o estabelecimento de uma hierarquia dentre grupos e indivíduos. Para a autora, o contexto histórico do Brasil da aliança dos colonizadores com a Igreja Católica Apostólica Romana que juntos promoveram o genocídio dos povos originários muito tem a dizer sobre a mentalidade de parte da sociedade atual (FISCHMANN, 2012, p. 18-20).

Assim, segundo a autora:

[...] Com a estrutura discriminatória instalada, estabeleceram-se privilégios de uns em detrimento de outros e não enfrentamos, ainda hoje, o que se passa com os descendentes desses grupos estigmados religiosamente, pois se lhes negou a alma, na esfera religiosa, o que se negou a eles foi a condição e a dignidade humana. (FISCHMANN, 2012, p. 19-20)

Logo, se um Estado não deve privilegiar determinada religião, também é seu papel cuidar para que uma religião, mesmo que tenha estatisticamente maior número de adeptos, possa determinar os ritos de uma outra religião, principalmente no âmbito legislativo, ainda que seus fiéis representem número significativo dentro do Congresso e do Senado. Dessa forma, Fischmann (2012, p. 23) cita Lafer (2007): “se determinado grupo religioso não concorda com determinada conduta, nada impedirá que esse grupo recomende aos seus que não pratiquem, em suas vidas privadas, o que prega sua doutrina".

Assim, Fischmann (2012, p. 24) arremata seu raciocínio dizendo que a justiça não se estabelece pelo domínio sob as consciências, mas sim pela condecoração das diversidades, de modo que a dignidade humana esteja efetivamente presentes para toda e qualquer pessoa independente de sua crença ou da ausência dela. Tendo a América Latina um histórico marcado pelo autoritarismo, a autora chama atenção para a imposição que determinadas religiões hegemônicas tentam estabelecer sobre os demais, principalmente aos que não são a ela adeptos e cita Bobbio:

Pode valer a pena pôr em risco a liberdade fazendo com que ela beneficie também o seu inimigo, se a única alternativa possível for restringi-la até o ponto de fazer sufocar, ou, pelo menos, de não lhe permitir dar a todos os 
seus frutos. É melhor uma liberdade sempre em perigo, mas expansiva, do que uma liberdade protegida, mas incapaz de se desenvolver. Somente uma liberdade em perigo é capaz de se renovar. Uma liberdade incapaz de se renovar transforma-se, mais cedo ou mais tarde, numa nova escravidão. (BOBBIO, 1992, p. 214, citado por FISCHMANN, 2012, p. 24)

De acordo com Zylbersztajn, Denise Carreira, relatora do Direito Humano à Educação da Plataforma Brasileira de Direitos Humanos Econômicos, Sociais e Culturais teria identificado "sérios problemas de intolerância religiosa nas escolas do país, especialmente quanto às religiões de matriz africana" (ZYLBERSZTAJN , 2012, p. 167). Denise teria recebido uma série de denúncias no contexto da violação a livre manifestação da crença.

No mesmo sentido, teria observado a relatora Farida Shaheed do Direito Humano à cultura da Organização das Nações Unidas (ONU) em uma missão ao Brasil realizada em novembro de 2010, quando notou que as religiões de matriz africanas eram negligenciadas pelos professores e diretores nas matérias de ensino religioso (ZYLBERSZTAJN , 2012, p. 167).

Dessa forma, o debate estabelecido entre os principais argumentos que permeiam a questão do direito fundamental à liberdade de crença em oposição à proteção animal, objeto do presente trabalho, aborda a horizontalidade das garantias fundamentais que devem ser aplicadas ao caso concreto.

Segundo Ana Beatriz Gonçalves de Carvalho; Delano Carneiro da Cunha (2014), o Brasil é um país multicultural formado por uma sociedade culturalmente heterogênea, fazendo com que direitos fundamentais e culturais possam entrar em conflito. Algumas religiões de matriz africana admitem a prática do sacrifício de animais, cuja carne vem a ser consumida durante seus rituais. Segundo os autores, o sacrifício constituiu uma prática milenar fundamentada na crença dessas religiões, assim como em outras, assim como praticam os muçulmanos.

Nesse sentido, esclarecem os autores que:

Inicialmente, vale esclarecer que o sacrifício de animais em rituais não constitui prática exclusiva das religiões de matriz africana [...]; Além disso, não são todas as religiões de matriz africana que admitem a prática do sacrifício de animais durante seus rituais, dentre as que admitem, deve-se compreender: o Candomblé, o Batuque, o Omolokô, a Santeria e a Umbanda. O sacrifício ritualístico de animais, não é feito de forma arbitrária, caracterizando-se 
por ser um dogma dessas religiões, praticado milenarmente [...]. (CARVALHO; CÂMARA, 2014)

Nos casos em que ocorre colisão de princípios, o peso entre eles deve ser mediado e ponderado para as circunstâncias do caso concreto para atender, da melhor forma possível, a justiça, a paz social e o bem comum. No cerne dos conflitos entre direitos fundamentais, deve ser observado sem a supressão de um pelo outro, de modo que seja considerada a importância relativa que cada um representa de forma em que se opte por aquele que, na situação presente, represente a menor diminuição do outro (CARVALHO; CÂMARA, 2014).

Para Carvalho; Câmara (2014), suprimir o direito de tais práticas violaria os princípios constitucionais da liberdade de crença e religião, manifestada no art. $5^{\circ}$, inciso VI da Lei Maior. Segundo os autores, os animais eventualmente utilizados durante os sacrifícios das religiões afro-brasileiras são cabras, codornas, galinha de angola, galos ou patos, considerados pela sociedade como "animais domésticos ou domesticados em cativeiro", e são, ainda, de certa forma, animais presentes na alimentação costumeira dos brasileiros. Tais observações retomam, mais uma vez, o estranhamento em relação à tamanha obstinação e empenho de esforços no sentido de inferiorizar a cultura e a identidade dessas religiões.

Nesse sentido, dispõe a Lei Maior:

Art. 225. Todos têm direito ao meio ambiente ecologicamente equilibrado, bem de uso comum do povo e essencial à sadia qualidade de vida, impondose ao Poder Público e à coletividade o dever de defendê-lo e preservá- lo para as presentes e futuras gerações.

$\S 1^{\circ}$ Para assegurar a efetividade desse direito, incumbe ao Poder Público: [...].

VII - proteger a fauna e a flora, vedadas, na forma da lei, as práticas que coloquem em risco sua função ecológica, provoquem a extinção de espécies ou submetam os animais a crueldade. (BRASIL, 1998)

Por essa perspectiva, resta claro que os animais utilizados nos cultos das religiões afrobrasileiras não se enquadram nas espécies em extinção e nem são submetidos a tratamentos considerados cruéis, sendo o "sofrimento" equivalente ao mesmo do processo de abatimento dos animais destinados para abastecer os comércios de todo o país. Também se deve levar em consideração que, logo após os rituais denominados de "corte", sua carne é oferecida para consumo alimentar dos praticantes da fé, assim como comumente encontram-se presentes na 
alimentação da população brasileira.

Dessa forma, Carvalho; Câmara (2014) cita Norberto Bobbio (2004) para elucidar a solução de conflitos culturais no âmbito da coletividade, o que se encaixa perfeitamente no seio da sociedade brasileira onde os preceitos cristãos costumam se colocar acima das demais crenças:

Aparentemente, trata-se de um caso de conflito entre razão teórica e razão prática, entre aquilo que devo crer e aquilo que devo fazer. Na realidade, trata-se de um caso de conflito entre dois princípios morais: a moral da coerência, que me induz a pôr minha verdade acima de tudo, e a moral do respeito ou da benevolência em face do outro. (BOBBIO, 2004, p. 191, citado por CARVALHO; CÂMARA, 2014)

Assim, entende-se que o real conflito, nesse caso, ocorre entre o princípio moral das pessoas, elucidando um embate de valores que se apresenta muito mais aparente do que concreto. Tudo isso, por conseguinte, dentro de uma sociedade que costumeiramente apresenta estranheza às práticas e religiões de matriz africana devido a um processo histórico de preconceitos e inferiorização que atualmente se reflete nas instâncias legislativas. Dessa forma, sob o pretexto da defesa dos animais, angariam proibir o culto e o sacrifício dos bichos, refletindo a perseguição a essas religiões através de um racismo institucionalizado.

Logo se percebe que se a questão fosse, realmente, a proteção animal, estar-se-ia investindo em outros aspectos meritórios dessa matéria, como o sofrimento dos animais nos rodeios, o abate humanizado negligenciado nos abatedores, dentre outros, e não na insistência em problematizar o ritual das religiões afro-brasileiras que operam o corte de maneira humanizada e utilizam a carne para consumo.

Por isso, é necessário para a garantia dos direitos individuais e coletivos e do próprio Estado Democrático de Direito que as contradições apresentadas no âmbito de uma sociedade multicultural não se pautem apenas nas demandas dominantes sob a escusa da defesa de preceitos constitucionais. Ressalta-se, ainda, importância à sensibilidade com a religião, à manifestação cultural e a identidade das minorias.

\section{O SACRIFÍCIO DA HIPOCRISIA: O RACISMO RELIGIOSO E O DISCURSO DA PROTEÇÃO ANIMAL}


A partir da análise do referido trâmite, com base em trechos dos votos dos relatores envolvidos, na jurisprudência pátria e na horizontalidade dos princípios constitucionais trabalhados ao longo do artigo, concluir como tais investidas de proibição da imolação de animais em rituais religiosos revestem-se de racismo sob o discurso da proteção ao meio ambiente - considerando o histórico de discriminação deste grupo ao longo da história, bem como a composição cristã-conservadora do legislativo, que insiste em proibir um fundamento das religiões afro, contradizendo-se na medida em que fecha os olhos para outras questões ambientais indiscutivelmente mais graves, como por exemplo, as condições extremamente cruéis existentes em frigoríficos clandestinos.

A visão distorcida sobre a cosmologia afro na composição religiosa brasileira, com base no racismo religioso, ou seja, com base no processo de discriminação com base na religiosidade negra, associada a concentração de poder a determinadas religiões cristãs, localizadas nas esferas legislativas, não só na esfera nacional, mas também municipal, compõe elementos destruidores do pilar republicano brasileiro de separação do estado de qualquer determinação religiosa central. A laicidade do estado é uma proteção constitucional e dos direitos fundamentais de toda população brasileira.

Assim, o presente projeto de lei é expressão primeira desta violação e merece atenção nos debates não só de resguardo dos direitos fundamentais a liberdade de crença e culto, mas principalmente de respeito a diversidade religiosa brasileira.

\section{REFERÊNCIAS BIBLIOGRÁFICAS}

BRASIL, Constituição Federal, 1988.

Decreto no $119-A$, de 7 de janeiro de 1890.

CARVALHO, Ana Beatriz Gonçalves de; CÂMARA, Delano Carneiro da Cunha. Liberdade religiosa e sacrifício de animais. Revista Jus Navigandi, ISSN 1518-4862, Teresina, ano 19, n. 3928, 3 abr. 2014. Disponível em: <https://jus.com.br/artigos/27281>. Acesso em abril de 2017.

D’Oliveira, Maria C. B. Breve análise do princípio da isonomia, 2011. Disponível em: $<$ http://institutoprocessus.com.br/2012/wp-content/uploads/2011/12/3_edicao1.pdf $>$. Acesso em abril de 2017.

HALL, Stuart. 2003. Da diáspora: identidades e mediações culturais. Tradução Adelaine. In: 
SOVIK, Liv (org.). La Guardiã Resende. Belo Horizonte: Editora UFMG; Brasília: representação da UNESCO no Brasil.

A identidade cultural na pós-modernidade. Tradução de Tomaz Tadeu da Silva e Guacira Lopes Louro. Rio de Janeiro: Lamparina, 2014

LAICIDADE, Associação República e Laicidade. O que é laicidade? Disponível em: $<$ http://www.laicidade.org/documentacao/textos-criticos-tematicos-e-de-reflexao/aspl/> .

Acesso em abril de 2017.

MBEMBE, Achille. Crítica da razão negra. Lisboa: Antígona, 2014.

Necropolítica. Espanha: Melusina, 2006.

MAMEDE, Mateus Lúcio. Constitucionalidade e inconstitucionalidade, proteção das diretrizes constitucionais e os tipos de inconstitucionalidade. In: Âmbito Jurídico, Rio Grande, XV, n. 98, mar 2012. Disponível em: <http://www.ambitojuridico.com.br/site/index.php?n_link=revista_artigos_leitura\&artigo_id=11234 $>$. Acesso em abril de 2017.

MARINHO, Marcos S. A validade jurídica do uso de argumentos religiosos no processo legislativo brasileiro, 2017. 81 folhas. Dissertação de Mestrado - Universidade Federal de Juiz de Fora, Juiz de Fora - Minas Gerais.

PINHEIRO, Douglas A. R. Direito, Estado e Religião: A constituinte de 1987/1988 e a (re)construção da identidade religiosa do sujeito constitucional brasileiro, 2008. 129 folhas. Dissertação de Mestrado - Universidade de Brasília, Brasília - DF. Disponível em: < http://repositorio.unb.br/bitstream/10482/1087/1/DISSERTACAO_2008_DouglasAntonioRPi nheiro.pdf $>$. Acesso em abril de 2017.

RAMOS, Luciana de Souza. O Direito Achado em Uganda: justiça diaspórica e combate ao racismo jurisdicional. Artigo publicado na Revista on line Instituto Humanitas Unisinos, 2018. Disponível em: http://www.ihu.unisinos.br/78-noticias/577807-o-direito-achado-emuganda-justica-diasporica-e-combate-ao-racismo-jurisdicional. Acesso em 11 de março de 2019.

Ilu Ayiê: a ancestralidade como categoria para compreensão dos Direitos Humanos na América Latina. GEHIM (Org.). Artigo publicado no VII Cóloquio de História e Imagem e I Colóquio Visualidades não-européias. Goiânia, GO, 2017. Disponível em: https://www.historia.ufg.br/p/25825-grupo-de-estudos-de-historia-e-imagem-gehim. Acesso em: 11 de março de 2019.

ROSELI, Fischmann. Estado laico, educação, tolerância e cidadania: para uma análise da concordata Brasil-Santa fé. São Paulo: Factash Editora, 2012. Disponível em: $<$ http://www.hottopos.com/ebooks/ESTADO\%20LAICO.pdf $>$. Acesso em abril de 2017. 
RUSSAR, Andrea. Brasil: a Laicidade e a Liberdade Religiosa desde a Constiuição da República Federativa de 1988, 2012. Disponível em: < http://www.egov.ufsc.br/portal/conteudo/brasil-laicidade-e-liberdade-religiosa-desdeconstitui $\% \mathrm{C} 3 \% \mathrm{~A} 7 \% \mathrm{C} 3 \% \mathrm{~A} 30-$ da-rep $\% \mathrm{C} 3 \%$ BAblica-federativa-de-1988 $>$. Acesso em abril de 2012.

ZYLBERSZTAJN, Joana. O princípio da Laicidade na Constituição de 1988, 2012. 225 folhas. Tese de Doutorado - Universidade de São Paulo, São Paulo, março de 2012. 